\title{
СИСТЕМА ПІДГОТОВКИ ОФІЦЕРСЬКИХ КАДРІВ СУХОПУТНИХ ВІЙСЬК У ЗБРОЙНИХ СИЛАХ АВСТРО- УГОРЩИНИ НАПЕРЕДОДНІ ПЕРШОЇ СВІТОВОЇ ВІЙНИ
}

Висвітлюються питання особливостей системи підготовки офіцерських кадрів сухопутних військ у збройних силах Австро-Угорщини, в хронологічному порядку з 70-х рр. XIX ст. і до Першої світової війни. Розглядаються особливості структури збройних сил, історія створення системи навчальних закладів для фахової підготовки офіцерів збройних сил, зокрема академій, шкіл кадетів та офіцерських фахових курсів.

Ключові слова: Збройні сили Австро-Угорщини, фахова підготовка офіцерів, військові академії, школи кадетів, однорічні добровольці.

Постановка проблеми. Збройні сили Австро-Угорської монархії були багатонаціональними та базувалися на принципах загального військового обов'язку і територіальному формуванні військових частин. Концепт - «багатонаціональні збройні сили» більшість дослідників того часу і сучасності вважають основним недоліком австро-угорської армії. Ця концепція була широко розповсюджена у німецькій військовій думці як оціночний фактор збройних сил Австро-Угорської імперії. 3 такою оцінкою були знайомі і австрійські військові кола. Особливості політичного облаштування «двоєдиної» монархії, потрійна система збройних сил, згадана вже багата національна палітра монархії - все це було викликами для збройних сил. Однією з проблем, яку австроугорські збройні сили змогли, в цілому, вирішити - створення єдиної для всіх трьох частин армії системи підготовки і виховання офіцерських кадрів. На жаль ця проблема не повною мірою досліджена у вітчизняній історіографії, хоча значна частина офіцерів колишньої австро-угорської армії, взяла безпосередню участь в українському державотворчому процесі.

Метою публікації є ознайомлення із системою й основними принципами підготовки офіцерських кадрів сухопутних військ у збройних силах Австро-Угорщини.

Лоссв Олександр Сергійович, асистент кафедри сходознавства Львівського національного університету імені Івана Франка, м. Львів.

(С) Лосєв O.C., 2018 
Аналіз попередніх досліджень. Практично єдиними публікаціями у сучасній українській історіографії з питань системи підготовки офіцерських кадрів та системи військової підготовки населення «двоєдиної» монархії є статті київського історика-дослідника Дмитра Адаменка. Вони представлені на його сайті: ah.milua.org, присвяченому історії Австро-Угорщини. Серед сучасних зарубіжних дослідників слід відзначити дослідження американського професора угорського походження Іштвана Деака, присвячені історії та розвитку офіцерського корпусу збройних сил АвстроУгорщини, повсякденному життю офіцерів та їх підготовці, а також національним проблемам в армії. Цікавою $є$ тематична праця австрійського дослідника Герхарда Яначека щодо розвитку системи військової освіти та повсякденного життя вихованців військових навчальних закладів в Австро-Угорщині. Розвиток військової освіти та навчальні військові заклади в угорському королівстві розглядаються у статтях угорського дослідника Жолтана Міклоша. Інформативним є електронний ресурс: the AustroHungarian Army 1914-18, заснований на дослідженнях військовопольової пошти британського полковника Джона Фредеріка Диксон-Натталла. Попри таку вузьку тему на сайті досить розгорнуто представлена структура збройних сил Австро-Угорщини, подається інформація про систему підготовки офіцерів напередодні та в роки Першої світової війни. Ще одним електронним джерелом $є$ австрійський сайт weltkriege.at, звідки був взятий австрійський закон про військовий обов'язок (Wehrgesetz), у редакції 1912 р., що чітко регламентує вимоги до кандидатів на звання офіцерів резерву та умови здобуття цього звання у різних родах військ. До джерельної бази щодо питання історії установ військової освіти «двоєдиної» монархії можна віднести довідники 3 військового та цивільного викладацького і виховательського персоналу військових навчальних закладів, а також довідники офіцерського та чиновницького складу армії, ландверу і гонведу. Для цієї статті автор користався даними довідника-шематизмусу (Schematismus) ландверу за 1914 р. Ще одним джерелом, на жаль не позбавленим деяких недоліків, є фундаментальна праця у двох частинах «Вооруженные силы Австро-Венгрии», видана Головним управлінням Генерального штабу російської імператорської армії у 1912 р. У першій частині цієї праці подається інформація про систему підготовки офіцерського складу збройних сил Австро-Угорщини. 
Mema cmammi. Висвітлення питань системи підготовки офіцерських кадрів сухопутних військ у збройних силах АвстроУгорщини напередодні Першої світової війни.

Виклад основного матеріалу. Особливість устрою «двоєдиної» Австро-Угорської монархії значно вплинула на організацію збройних сил імперії. Нагадаємо, 21 грудня 1867 р. Імперський парламент прийняв 6 конституційних законів один 3 яких остаточно оформлював «розлучення» Австрії та Угорщини i утворював формальний союз двох держав - Австрійської імперії та Угорського королівства. При цьому, за військовим законом 1868 р., Австрія і Угорщина утворювали деякі спільні міністерства, а саме: спільне військове міністерство, фінансове міністерство (тут слід додати, що одним із головних його завдань був контроль за податками на спільну армію) і міністерство іноземних справ. Якщо раніше назви імперських міністерств і установ містили предикат (kaiserliche-königliche) «імператорсько-королівський», що відображало службу імператору і королю з роду Габсбургів, то тепер з'являється нове визначення (kaiserlich und königlich) «імператорський і королівський» - для спільних установ Австрії та Угорщини, предикат (kaiserliche-königliche) залишився тільки для установ коронних земель Австрії i (königlich ungarische) «королівсько-угорський» - для установ земель угорської корони. Згодом довгі назви скоротили до абревіатур: k.u.k., k.k., k.u. У 1878 р. Австро-Угорщина окупувала, а в 1908 р. анексувала територію Боснії та Герцеговини, які так і не увійшли ані до складу земель австрійської корони, ані до складу угорської корони. Ця територія управлялася спільним міністерством фінансів.

Вже у 1889 р. закріпився остаточний розподіл збройних сил двоєдиної імперії, з яким вона і вступила у Першу світову війну:

- спільна армія (Gemeinsame Armee), яка включала у свій склад сухопутні сили (k.u.k.Heer) і військовий флот (k.u.k. Kriegsmarine), що формувалися з мешканців обох частин імперії, податки на яку також сплачували всі мешканці двоєдиної імперії;

- крайова оборона Австрії (K.K. LANDWEHR) і австрійське ополчення (K.K. LANDSTURM), які формувалися лише з громадян земель австрійської корони і фінансувалися податками 3 цих земель;

- крайова оборона Угорщини (K.U. LANDWEHR, або угор. MAGYAR KIRALYI HONVEDSEG - M.K. HONVED) і угорське 
ополчення (K.U. LANDSTURM або угор. M.K. NEPFELKELES), які формувалися лише 3 громадян земель угорської корони i фінансувалися податками з цих земель.

Тут треба зазначити, що королівство Хорватії і Славонії, згідно зі спільними домовленостями 3 угорським парламентом, також мало свої частини хорвато-словенської крайової оборони (хорв. domobrantsvo). Командною мовою у підрозділах спільних імперських армії та флоту, а також австрійського ландверу була німецька, у підрозділах гонведу - угорська, а у підрозділах домобранства - сербо-хорватська. Хоча домобранство і було окремою одиницею, воно підпорядковувалось спільному 3 гонведом міністрові національної оборони Угорщини, тому вважалося частиною гонведу.

1882 року, після запровадження загального військового обов’язку у Боснії та Герцеговині, там було створено декілька добровольчих боснійсько-герцеговинських батальйонів, кількість яких поступово зростала, і на 1893 рік їх налічувалося вже 11. 31 січня 1894 року почався процес інтеграції цих підрозділів у спільну армію, що завершився 1897 року. 3 цих батальйонів були створені чотири боснійсько-герцеговинські піхотні полки i, 1903 року - один окремий боснійсько-герцеговинський єгерський батальйон. Командною мовою у цих підрозділах була німецька, а полковою їх рідна, сербо-хорватська. «Босняки», як їх зазвичай називали, вважалися надійними солдатами імперії.

Розглядаючи систему підготовки майбутніх офіцерів у Австро-Угорщині, слід згадати про систему початкової військової освіти, метою якої було 3 дитячого віку прищепити любов до військової справи і виховати майбутнього командира. Ця система створювалася для спрямування iіi вихованців у військові академії та школи кадетів. Однією з особливих ідей цієї системи була турбота про військових сиріт (у даному контексті йдеться про сиріт офіцерів i військових чиновників), що повинно було підкреслити турботу монархії до своїх захисників. Втіленням цієї ідеї було заснування 1877 р. «Притулку для сиріт військових» у м. Фішау, з 1891 р. - «Освітній інститут для сиріт-синів офіцерів», а з 1911 р. - «Інститут офіцерських сиріт». У 1898 р. цей заклад був переведений у м. Хіртенберг, де проіснував до кінця монархії. За деякими даними [1, с. 169], цей навчальний заклад був розрахований на 120 місць. Сюди приймалися хлопчики не раніше 
шестирічного віку, навчання тривало чотири роки і мало на меті підготувати до вступу у молодшу (або нижчу) військову реальну школу, або цивільний навчальний заклад. Строк перебування у даному закладі - до 14 років. Діти цього навчального закладу були на державному утриманні. Система освіти відповідала загальній початковій освіті, до навчального процесу залучалися i жінки-вчителі [2].

Наступним етапом системи військової підготовки молоді були військові реальні школи. Вони поділялися на нижчі (або молодші) і вищі (або старші). Відповідно до реформи освіти у 1852 р. було створено 6 нижчих і 6 вищих військових реальних шкіл. Система освіти у них відповідала курсам початкової та старшої загальноосвітніх гімназій, але 3 елементами військової дисципліни і підготовки. У 1900 р. набули сили нові правила навчання у військових навчальних закладах, які визначали, у тому числі, форму навчання:

1. Безкоштовна і частково оплачувана - коштом стипендій, що засновувалися спільним військовим міністерством і міністерствами крайової оборони Австрії та Угорщини.

2. Безкоштовні і частково оплачувані відомчі державні, земельні, митні і приватні військові школи.

3. Платна для громадян Австрії та Угорщини [2].

Ця система дозволяла деяким категоріям учнів (наприклад, дітям-сиротам офіцерів і військових чиновників, або дітям офіцерів і військових чиновників чинної служби, або у відставці) навчатися за рахунок держави чи якоїсь стипендії, або мати суттєву знижку в оплаті навчання - половину суми. Оплата у військових реальних школах була 828 крон на рік [1, с. 169]. У нижчі навчальні школи приймали хлопчиків у 11-12 річному віці за заявою батьків, 3 обов'язковим медичним оглядом при зрості не нижче 125 см [4, с. 18]. Прийом абітурієнтів був позбавлений дискримінації в етнічному чи релігійному сенсі, вступні обов'язкові іспити абітурієнт складав будь-якою 3 офіційно визнаних у імперії мов, але подальше навчання здійснювалось німецькою (4 школи, що розташовувалися в австрійських землях) чи угорською мовами (2 школи). Термін навчання - чотири роки, мета - підготувати учня до вступу у вищу військову реальну школу, або у школу кадетів. Усього нижчі військові реальні школи були розраховані на 1188 навчальних місць [1, с. 169]. 
Деяким аналогом нижчих військових реальних шкіл був «Військовий пансіонат для хлопчиків» у столиці Боснії м. Сараєво, створений 1879 року. Офіційно він створювався для дітей офіцерів XV і XVI військових округів, що розташовувалися в окупованій Боснії та Герцеговині, але також мав на меті популяризувати військову кар'єру серед місцевого населення. Усього за період існування закладу з 1879 по 1914 у ньому пройшли навчання 1025 хлопчиків, 3 яких 346 - діти місцевих жителів [4, с. 12]. Система і терміни навчання відповідали нижчим військовим реальним школам.

Кількість вищих військових реальних шкіл постійно змінювалась у 1912-13 рр. навчальному році їх було лише дві, а вже у наступному 1913-14 н.р. - стало вже шість [3, с. III]. Термін навчання у них тривав три роки і відповідав програмі старших класів загальних гімназій, але з суровою військовою дисципліною і військовою підготовкою. Вступати у такі школи могли юнаки 14-16 річного віку, як після закінчення нижчих військових реальних шкіл, так і після початкових класів звичайних гімназій. Вступний іспит німецькою (або угорською) мовою, оплата за навчання - така сама, як і в нижчих школах [4, с. 36]. Основною метою навчання була підготовка до вступу у військові академії.

Нижче наводиться таблиця початкових військових навчальних закладів, військових реальних шкіл за даними 1913 р.

\begin{tabular}{|c|c|c|}
\hline $\begin{array}{c}\text { Назва закладу і місце його } \\
\text { розташування }\end{array}$ & Рік & Начальник школи \\
\hline $\begin{array}{l}\text { Інститут офіцерських сиріт } \\
\text { м. Хіртенберг } \\
\text { (k.u.k. Offizierswaiseninstitut) }\end{array}$ & $\begin{array}{l}1877 / \\
1911\end{array}$ & $\begin{array}{c}\text { Оберстлейтенант Роберт Росток } \\
{[3, \text { с. } 1]}\end{array}$ \\
\hline $\begin{array}{l}\text { Військовий пансіонат для хлопчиків } \\
\text { м. Сараєво (Militärknabenpensionat) }\end{array}$ & \begin{tabular}{c|c|}
$1879 /$ \\
1903 \\
\end{tabular} & $\begin{array}{c}\text { Майор Адальберт Наглік фон Гліна } \\
{[3, \text { с. } 82]}\end{array}$ \\
\hline $\begin{array}{l}\text { Нижчя військова реальна школа } \\
\text { м. Еннс (Militär-Unterrealschule) }\end{array}$ & 1908 & Оберст Карл Смутни [3, с. 3] \\
\hline $\begin{array}{c}\text { Нижчя військова реальна школа } \\
\text { м. Фішау }\end{array}$ & 1898 & Оберстлейтенант Карл Цан [3, с. 6] \\
\hline $\begin{array}{c}\text { Нижчя військова реальна школа } \\
\text { м. Кьошег }\end{array}$ & 1874 & Оберст Фердінанд Йержабек [3, с. 8] \\
\hline $\begin{array}{c}\text { Нижчя військова реальна школа } \\
\text { м. Марошвашаргелі } \\
\end{array}$ & \begin{tabular}{|l|l|}
$1879 /$ \\
1909 \\
\end{tabular} & $\begin{array}{c}\text { Оберстлейтенант Оттокар Кунст } \\
{[3, \text { с. } 11]}\end{array}$ \\
\hline $\begin{array}{c}\text { Нижчя військова реальна школа } \\
\text { м. Санкт Пьольтен }\end{array}$ & 1875 & $\begin{array}{c}\text { Оберстлейтенант Оттокар Партль } \\
{[3, \text { с. } 14]}\end{array}$ \\
\hline $\begin{array}{c}\text { Нижчя військова реальна школа } \\
\text { м. Штрасс }\end{array}$ & $\begin{array}{c}1881 / \\
1904\end{array}$ & $\begin{array}{c}\text { Оберстлейтенант Рудольф } \\
\text { Епельтауер [3, с. 17] }\end{array}$ \\
\hline $\begin{array}{c}\text { Вища військова реальна школа } \\
\text { м. Кашау }\end{array}$ & 1913 & Майор Арпад Альбрехт [3, с. 20] \\
\hline
\end{tabular}


Продовження табл.

\begin{tabular}{|c|c|c|}
\hline $\begin{array}{c}\text { Назва закладу і місце його } \\
\text { розташування }\end{array}$ & Рік & Начальник школи \\
\hline $\begin{array}{c}\text { Вища військова реальна школа } \\
\text { м. Кішмартон }\end{array}$ & 1909 & $\begin{array}{c}\text { Оберстлейтенант Людвіг Штрокай } \\
\text { [3, с. 22] }\end{array}$ \\
\hline $\begin{array}{c}\text { Вища військова реальна школа } \\
\text { м. Краків }\end{array}$ & 1913 & Майор Мечислав Кулінський [3, с. 25] \\
\hline $\begin{array}{c}\text { Вища військова реальна школа } \\
\text { м. Маріш-Вайскірхен }\end{array}$ & 1875 & Оберст Франц Латцер [3, с. 27] \\
\hline $\begin{array}{c}\text { Вища військова реальна школа } \\
\text { м. Марбург }\end{array}$ & 1913 & $\begin{array}{c}\text { Оберстлейтенант Вільгельм } \\
\text { Мартінек [3, с. 31] }\end{array}$ \\
\hline $\begin{array}{c}\text { Вища військова реальна школа } \\
\text { м. Пожони }\end{array}$ & 1913 & $\begin{array}{c}\text { Майор Йоганн Тільцер } \\
\text { [3, с. 33] }\end{array}$ \\
\hline $\begin{array}{c}\text { Вища військова реальна школа } \\
\text { ландверу м. Відень }\end{array}$ & 1912 & $\begin{array}{c}\text { Оберст ген.штабу Генріх Віеден } \\
\text { Едлер фон Альпенбах [7, с. 399] }\end{array}$ \\
\hline
\end{tabular}

Одним 3 основних джерел поповнення офіцерського складу збройних сил двоєдиної імперії були школи кадетів. Тут треба зазначити деякі особливості австрійської системи підготовки офіцерського складу. Школи кадетів не готували офіцерів, а лише кандидатів на офіцерський чин. Випускникам цих шкіл, у разі успішного закінчення, присвоювалось звання «кадет» (до 1908 р. кадет-заступник офіцера, 31908 - фенріх). Тому ці навчальні заклади і отримали свою назву «школи кадетів». Кадет після закінчення школи вступав у підрозділ на стройову посаду, де повинен був прослужити не менше одного року, отримати від начальства схвальну атестацію по службі, а від офіцерського складу підрозділу - згоду на присвоєння первинного офіцерського звання - лейтенант. Як правило, кадети, а згодом, фенріхи служили у своєму званні до отримання звання лейтенанта 2-3 роки. Досить часто у вітчизняній літературі трапляється помилковий переклад звання фенріх як прапорщик. Хоча дослівно корені цих слів і відносяться до значення слова «прапор», проте самі звання, а точніше ранги - абсолютно різні. Прапорщик у збройних силах Російської імперії - первинне офіцерське звання осіб, що не закінчували військових навчальних закладів, проте мали певний освітній ценз та могли перебуваючи на військовій службі, добровільно скласти іспити на чин. У 1912 року в ході підготовки до великої війни царем Миколою II був підписаний наказ на випадок мобілізації про прискоренні випуски військових та спеціальних навчальних закладів, випускникам яких також присвоювали цей чин $[10$, с. 387]. Згодом 3'являються спеціалізовані навчальні заклади - школи прапорщиків. Проте у збройних силах Російської імперії прапорщик - це вже офіцер, а фенріх в Австро-Угорщині лише кандидат в офіцери. 
За підрахунками автора, школи кадетів у Австро-Угорщині забезпечували від 4/5 на початку XX ст. до $2 / 3$ річної потреби офіцерського кадру. Від $1 / 5$ до $1 / 3$ забезпечували випускники військових академій. На відміну від шкіл кадетів випускники академій, у разі успішного складання іспитів, одразу отримували первинні офіцерські звання лейтенантів.

Вперше в австрійській армії проблему спеціальної підготовки офіцерського складу визначила імператриця Марія-Терезія у 1740 р. До цього часу офіцерський патент можна було просто придбати за гроші. Вже у 1751 р. була відкрита «Школа військових вихованців» для навчання військовій справі 100 дітей бідних дворян i офіцерів. У 1752 р. у Вінер-Нойштадті з'являється перша школа кадетів «Cadetenhauses» 3 тією ж метою, але із залученням вихідців із всіх верств населення. Так в імперії почалася історія закладів військової підготовки майбутніх офіцерів. Одним із важливих кроків щодо вдосконалення системи військового навчання був проект 1869 р. оберста Пехмана фон Массена, за яким створювалися спеціалізовані школи кадетів для підготовки кандидатів на офіцерський чин, без закінчення академії. Тоді ж 13 вже існуючих військових шкіл були переформовані у школи кадетів. Продовженням процесу вдосконалення системи військового навчання став проект оберста генерального штабу Адольфа фон Вурмба [8], поданий у 1874 р., який передбачав адаптацію навчального курсу 3 цивільними гімназіями, збільшуючи строк навчання до 4-х років. У 1875 р. цей проект ліг в основу реформи військової освіти.

Загалом, на початку XX ст. існувало 17 шкіл кадетів піхоти, 1 школа кадетів артилерії, 1 школа кадетів кавалерії, 1 школа кадетів інженерних військ, курс кадетів обозних військ при Празькій школі кадетів піхоти, курс кадетів санітарних військ, при Будапештській школі кадетів піхоти, 1 школа кадетів ландверу, 2 школи кадетів гонведу. Цікаво, що зазначені вище школи кадетів, відповідно до адміністративно-політичного поділу двоєдиної монархії, підпорядковувались трьом міністерствам. Спільному військовому міністерству підпорядковувалися всі школи кадетів піхоти, кавалерії, артилерії, інженерних військ та курси при них, міністерству крайової оборони Австрії - школа кадетів ландверу у Відні, міністерству крайової оборони Угорщини - школи кадетів гонведу у Надьвараді і Печі. Таке 
підпорядкування могло б спричинити чимало проблем з різними вимогами та стандартами підготовки, проте проект згаданого вище Адольфа фон Вурмба передбачав єдині стандарти підготовки у військовій освіті. Тому випускники шкіл кадетів до кінця існування монархії навчалися за єдиними програмами підготовки [8].

Вступити у школу кадетів можна було з 14 до 17 років, і від абітурієнтів вимагалося задовільне фізичне здоров'я і достатня успішність у навчанні для складання вступного іспиту. Навчання було платним - 300 крон на рік, але для дітей військовослужбовців передбачалася пільгова платня. Наприклад, за сина офіцера резерву чи резерву ландверу потрібно було сплатити лише 160 крон, а за сина офіцера чи військового чиновника чинної служби лише 24 крони! Решту видатків сплачувала держава [1, с. 170]. Щоправда, держава вимагала за це відслужити у збройних силах після закінчення не менше трьох років за кожен рік навчання. Повний курс навчання тривав 4 роки. Виняток - школа кадетів кавалерії, там термін - 3 роки, але вступити до неї можна було тільки після закінчення 1-го курсу школи кадетів піхоти. Учнів шкіл кадетів називали «цолінги». Як зазначалося вище, курс навчання відповідав дисциплінам цивільних навчальних закладів, першого-третього року навчання - відповідно 5-6 рік гімназії або реальної школи, а четвертий рік навчання - курсу старшої гімназії або курсу старшої реальної школи. До навчального плану, наприклад школи кадетів піхоти, входили наступні дисципліни: німецька і французька мови, географія, історія, математика, фізика, хімія, геометрія, креслення і малювання та низка військових дисциплін - військові устави, організація збройних сил, зброя, інженерна підготовка, стройова підготовка, тактика, військова топографія. Викладання в школах велося німецькою мовою, але у школах, що розташовувалися на території угорського королівства і у класах артилерійської та кавалерійської шкіл, деякі предмети викладалися угорською. Відповідно до умов Угорсько-Хорватської умови 1868 р., за яким королівство Хорватія і Славонія входили на певних умовах до складу земель угорської корони, у школах кадетів піхоти, що розташовувалися на території цього королівства у містах Карлштадт (суч. Карловац) і Каменіц (суч. Сремська Камениця), замість угорської мови викладали сербо-хорватською мовою. У школі кадетів ландверу викладання велося повністю німецькою 
мовою, а в школах кадетів гонведу - угорською. Загалом мовна ситуація у державі, і зокрема у збройних силах, змушувало військове керівництво готувати офіцерський склад зі знанням не тільки іноземних мов, але і декількох $з$ десяти визнаних у імперії мов. Починаючи 31870 р., Військове міністерство проводило збір та публікацію статистичних даних про вивчення офіцерами мов.

Нижче наводиться таблиця вивчення офіцерами офіційно визнаних мов імперії (виключаючи німецьку) [5, с. 100].

\begin{tabular}{|l|c|l|c|}
\hline \multicolumn{2}{|c|}{1870} & \multicolumn{2}{c|}{1904} \\
\hline Мова & $\begin{array}{c}\text { Відсоток тих, } \\
\text { які вивчають }\end{array}$ & \multicolumn{1}{c|}{ Мова } & $\begin{array}{c}\text { Відсоток тих, } \\
\text { які вивчають }\end{array}$ \\
\hline 1. Італійська & 32,76 & 1. Чеська & 47,0 \\
\hline 2. Чеська & $30,182$. & 2. Угорська & 33,6 \\
\hline 3. Угорська & 19,77 & 3. Польська & 19,3 \\
\hline 4. Польська & 17,62 & 4. Сербо-хорватська & 15,3 \\
\hline 5. Сербо-хорватська & 17,36 & 5. Румунська & 8,8 \\
\hline 6. Румунська & 8,95 & 6. Італійська & 8,5 \\
\hline 7. Русинська & 5,14 & 7. Русинська & 7,8 \\
\hline 8. Словенська & 5,11 & 8. Словенська & 7,3 \\
\hline 9. Словацька & - & 9. Словацька & 6,9 \\
\hline
\end{tabular}

Із графи відсотків можна побачити, що певна кількість офіцерів вивчала дві або і три мови.

В угорському гонведі ситуація бала дещо іншою. Мадяри спромоглися на рівні свого законодавства ввести угорську мову як єдину командну мову і мову підрозділів. Це не стосувалося хорватсько-словенської домобрани, де командною мовою i мовою підрозділів була сербо-хорватська мова, і де офіцерський склад був хорватським.

Школи розташовувалися таким чином, щоб представляти усі регіони імперії. Загальна кількість кадетів у школах, за даними 1912 р., сягала 3107 осіб [1, с. 170]. У 1913 р. була проведена чергова реорганізація військових навчальних закладів, у результаті якої 4 школи кадетів піхоти (м. Лобзов біля м. Краків, м. Марбург (суч. Марібор), м. Каша (суч. Кошице), м. Прессбург (суч. Братислава)) переформовувалися у вищі військові реальні школи. У 1904 і 1907 рр. були перепрофільовані школи у м. Штрасс-ін-Штаєрмаркі у м. Трієст. Також школа кадетів інженерних військ у 1913 р. була приєднана до Технічної військової академії у Мьодлінгу. Це було необхідно у зв'язку із підвищенням вимог до підготовки майбутніх офіцерів.

Також відбулися зміни і в австрійському ландвері, у 1912 р. школа кадетів ландверу була переформована у Військову 
академію ландверу Франца Йосифа, а також при академії відкривається вища військова реальна школа ландверу.

Нижче наводиться таблиця шкіл кадетів за даними 1914 р.

\begin{tabular}{|c|c|c|}
\hline $\begin{array}{c}\text { Назва школи } \\
\text { і місце іï розташування }\end{array}$ & $\begin{array}{c}\text { Рік засну- } \\
\text { вання }\end{array}$ & Начальник школи \\
\hline $\begin{array}{l}\text { Школа кадетів піхоти м. Відень } \\
\text { (Infanteriekadettenschule) }\end{array}$ & 1869 & $\begin{array}{l}\text { Оберстлейтенант } 4 \text { боснійсько- } \\
\text { герцеговинського полку піхоти } \\
\text { Фрідріх Томанек Едлер фон } \\
\text { Беєрфельд [3, с. } 70]\end{array}$ \\
\hline $\begin{array}{l}\text { Школа кадетів піхоти } \\
\text { м. Будапешт }\end{array}$ & $\begin{array}{l}1869 / \\
1875\end{array}$ & $\begin{array}{l}\text { Оберстлейтенант } 39 \text { полку піхоти } \\
\text { Віктор Мога }[3, \text { с. } 48]\end{array}$ \\
\hline Школа кадетів піхоти м. Прага & $1869 / 1875$ & $\begin{array}{l}\text { Майор } 95 \text { полку піхоти Антон } \\
\text { Тлусти }[3, \text { с. } 65]\end{array}$ \\
\hline $\begin{array}{l}\text { Школа кадетів піхоти } \\
\text { м. Кьонігсфельд (суч. м. Брно) }\end{array}$ & $\begin{array}{l}1869 / \\
1877\end{array}$ & $\begin{array}{l}\text { Майор } 8 \text { полку піхоти Едуард } \\
\text { Прокеш [3, с. } 57]\end{array}$ \\
\hline $\begin{array}{l}\text { Школа кадетів піхоти } \\
\text { м. Інсбрук }\end{array}$ & $1869 / 1875$ & $\begin{array}{l}\text { Майор } 4 \text { полку тірольських єгерів } \\
\text { Альбрехт Путцкер [3, с. 51] }\end{array}$ \\
\hline $\begin{array}{l}\text { Школа кадетів піхоти } \\
\text { м. Темешвар (суч. Темешоара) }\end{array}$ & $1869 / 1875$ & $\begin{array}{l}\text { Майор } 19 \text { полку піхоти Фрідріх } \\
\text { Гланц [3, с. 68] }\end{array}$ \\
\hline $\begin{array}{l}\text { Школа кадетів піхоти } \\
\text { м. Надьсебен, (суч. Сібіу) }\end{array}$ & $1869 / 1875$ & $\begin{array}{l}\text { Оберстлейтенант } 31 \text { полку піхоти } \\
\text { Август Шпайс фон Браціофорте } \\
{[3, \text { с. } 63]}\end{array}$ \\
\hline $\begin{array}{l}\text { Школа кадетів піхоти } \\
\text { м. Лібенау біля м. Грац }\end{array}$ & 1876 & $\begin{array}{l}\text { Оберстлейтенант } 99 \text { полку піхоти } \\
\text { Фрідріх От [3, с. 61] }\end{array}$ \\
\hline $\begin{array}{l}\text { Школа кадетів піхоти } \\
\text { м. Карлштадт (суч. Карловац) }\end{array}$ & $1868 / 1880$ & $\begin{array}{l}\text { Оберстлейтенант } 4 \text { боснійсько-герце- } \\
\text { говинского полку піхоти Адольф } \\
\text { Курелец Ріттер фон Бойне-Мір [3, с. 55] }\end{array}$ \\
\hline $\begin{array}{l}\text { Школа кадетів піхоти } \\
\text { м. Каменіц (суч. Сремська } \\
\text { Камениця) }\end{array}$ & 1895 & $\begin{array}{l}\text { Майор боснійсько-герцеговинського } \\
\text { батальйону фельд’єгерів Інноценц } \\
\text { Бехаль [3, с. 53] }\end{array}$ \\
\hline $\begin{array}{l}\text { Школа кадетів піхоти } \\
\text { м. Лемберг (суч. Львів) }\end{array}$ & 1899 & $\begin{array}{l}\text { Майор } 15 \text { полку піхоти Габріель } \\
\text { Вернер [3, с. 59] }\end{array}$ \\
\hline $\begin{array}{l}\text { Школа кадетів кавалерії м. Маріш- } \\
\text { Baйскірхен (суч. Границ) } \\
\text { (Kavalleriekadettenschule) }\end{array}$ & 1878 & $\begin{array}{l}\text { Оберстлейтенант } 14 \text { полку драгунів } \\
\text { Маріо Франц [3, с. 75] }\end{array}$ \\
\hline $\begin{array}{l}\text { Школа кадетів артилерії } \\
\text { м. Трайскірхен } \\
\text { (Artilleriekadettenschule) }\end{array}$ & 1903 & $\begin{array}{l}\text { Оберстлейтенант арт.штаб. Людвіг } \\
\text { Меккель [3, с. 78] }\end{array}$ \\
\hline $\begin{array}{l}\text { Школа кадетів гонведу } \\
\text { м. Надьварад (суч. Орадя) } \\
\text { (готувала кадетів для піхоти і } \\
\text { кавалерії гонведу) }\end{array}$ & 1898 & $\begin{array}{l}\text { Оберстлейтенант } 28 \text { полку гонведу } \\
\text { Ріхард Міллер }\end{array}$ \\
\hline Школа кадетів гонведу м. Печ & 1898 & $\begin{array}{l}\text { Майор } 18 \text { полку гонведу Олександр } \\
\text { Туг фон Фельшу-Сопор }\end{array}$ \\
\hline
\end{tabular}

Ще одним джерелом підготовки офіцерського складу були військові академії, які, на відміну від шкіл кадетів, одразу 
готували і випускали офіцерів - лейтенантів. Рівень загальноосвітньої і військово-спеціальної підготовки був набагато вищим, до учнів висувались значно вищі вимоги щодо освітньої та фізичної підготовки, що у подальшому дозволяло випускникам робити більш успішну військову кар'єру. Так само як і для шкіл кадетів, для військових академій система підготовки, запропонована Адольфом фон Вурмбом, також передбачала єдині стандарти навчання.

До академій приймали юнаків 17-20 років, переважно тих, хто успішно закінчив військові вищі реальні школи (а з 1900 р. і цолінги шкіл кадетів, які «на відмінно» закінчили третій курс, могли на пільгових умовах вступати до академій), і успішно склали вступні іспити. Крім того, висувалися певні вимоги до стану фізичного розвитку і здоров'я. Навчання могло здійснюватися казенним коштом, або, як це вже зазначалося вище, відповідно до правил 1900 р. Повний кошт складав 1600 крон за один курс навчання. Повний курс навчання тривав 3 роки [1, с. 169]. Мова навчання - німецька, в академії гонведу - угорська. Після закінчення терміну навчання складали іспити перед комісією, що призначалася військовим міністерством. При успішному складанні іспитів 3 оцінкою не нижче «добре» випускникам присвоювалося звання «лейтенант». При оцінці «задовільно», як і випускникам шкіл кадетів, - звання «кадет», 31908 - «фенріх». Якщо оцінка була «незадовільно» випускали у військо у званні «фельдфебель», тобто старший унтерофіцер. Так само на випускників академій, як і шкіл кадетів, що повністю або частково навчалися казенним коштом, розповсюджувалося правило обов'язкового терміну служби у армії.

Загальна кількість тих, хто навчався у військових академіях, за даними 1912 р., становила: Терезіанська військова академія 450 осіб, Технічна військова академія - 270 осіб, Військова академія Людовіка - 300 осіб [1, с. 169-171].

Нижче наведена таблиця військових академій сухопутних військ за даними 1914 р.

\begin{tabular}{|l|c|l|}
\hline Назва академії і місце їі розташування & Рік & \multicolumn{1}{|c|}{ Начальник академії } \\
\hline $\begin{array}{l}\text { Терезіанська військова академія у } \\
\text { Вінер-Нойштадт м. Відень }\end{array}$ & 1751 & $\begin{array}{l}\text { Фельдмаршал-лейтенант Йозеф } \\
\text { Рот [3, с. 35] }\end{array}$ \\
\hline $\begin{array}{l}\text { Технічна військова академія у } \\
\text { Мьодлінгу м. Відень }\end{array}$ & 1756 & $\begin{array}{l}\text { Генерал-майор Георг Хефелле } \\
\text { [3, с. 40] }\end{array}$ \\
\hline $\begin{array}{l}\text { Класи піонерів при Технічній } \\
\text { військовій академії у м. Хайнбург }\end{array}$ & 1913 & $\begin{array}{l}\text { Оберстлейтенант 2 піонерного баталь- } \\
\text { йону Теодор Вейдінгер [3, с. 45] }\end{array}$ \\
\hline $\begin{array}{l}\text { Військова академія Франца Йосифа } \\
\text { м. Відень (ландвер) }\end{array}$ & 1912 & $\begin{array}{l}\text { Оберст ген.штабу Генріх Віеден } \\
\text { Едлер фон Альпенбах [7, с. 399] }\end{array}$ \\
\hline $\begin{array}{l}\text { Військова академія Людовіка } \\
\text { м. Будапешт (гонвед) }\end{array}$ & $\begin{array}{l}1808 / \\
1872\end{array}$ & $\begin{array}{l}\text { Генерал-майор Конрад Зіглер фон } \\
\text { Еберсвальд }\end{array}$ \\
\hline
\end{tabular}


Наступним важливим джерелом поповнення командного складу збройних сил, особливо у воєнний час, була система підготовки офіцерів резерву. Відповідно до «Військового закону» від 1869 р. і його подальших редакцій молоді люди, які на час призову (рік, коли призовнику виповнюється 21 рік), закінчили повний курс цивільної гімназії або реальної школи і отримали атестат зрілості (т.зв. матуру), мали право вступити на службу на правах «однорічного добровольця». Заявити про таке рішення потрібно було одразу після виповнення 17-річчя. Нагадуємо, що в Австро-Угорщині діяла загальна особиста військова повинність, кожен чоловік, здатний носити зброю, на 1 січня року, коли йому виповнювалося 19 років, заносився до списків австрійського або угорського ополчення, де перебував до досягнення 42-річного віку. У 20 років чоловік потрапляв у списки призовників, а в період 321 до 23 років - повинен був пройти жеребкування i медичний огляд, на основі якого визначалася його подальша доля: чинна служба у лавах збройних сил, зарахування у рекрутській запас або повне звільнення від військової служби. Цікаво, що ті чоловіки, які не були призвані на службу за медичними показаннями, через від’їзд за кордон, повинні були протягом 12 років сплачувати військовий податок. Також комісія розглядала, згідно 3 чинним законодавством, право на тимчасове відстрочення від служби, наприклад, особам, які бажали закінчити навчання, але лише до осені того року, коли їм виповнювалося 23 роки. Строк служби сягав 2-3 роки, залежно від роду зброї [9, I-V].

Основна мета «однорічних добровольців» - протягом одного року пройти військову службу і отримати звання «лейтенанта резерву». У всіх родах військ, крім кавалерії, «однорічники» могли проходити службу і навчання як за державний кошт, так і за власний, у кавалерії - тільки власним коштом [9, V].

Як відбувалась підготовка офіцерів резерву? Спочатку «однорічник» проходив звичайну 8-тижневу підготовку у стройовій частині, у період 31 грудня по 1 червня «однорічників» збирали у спеціальні школи, які відкривалися при всіх полках спільної армії та ландверу, у полках гонведу - при управліннях округів гонведу, у кавалерії й артилерії - при штабах бригад і т.п., де вони проходили програму скороченого курсу військових предметів шкіл кадетів. На чолі таких шкіл ставили відряджених офіцерів у ранзі гауптмана, характер навчання був строго практичним [1, с. 171-172]. 
Після успішного складання іспитів 3 теоретичних і практичних дисциплін «однорічники» отримували звання «титулярного фельдфебеля» (з 1909 р. - «кадет-аспірант резерву», з 1912 «кадет резерву») і поверталися дослужувати свої строки до своїх частин. Як правило, до 1 січня вони очікували присвоєння звання «фенріх резерву». Після того, звільнившись у резерв, протягом наступних трьох років, при проходженні обов'язкових військових зборів, вони отримували звання «лейтенант резерву». Якщо «однорічник» не міг скласти випускний іспит, його залишали на другій рік служби, повністю за казенний кошт. Якщо ж і після повторного курсу він не міг скласти іспиту, його звільняли у запас на загальних підставах, у званні унтер-офіцера. Загалом, за даними 1912 р., щорічно вступало у збройні сили близько 6,5 тисяч «однорічників», 75\% з яких успішно складало іспити.

Цікаво, що саме на останню категорію - офіцерів резерву ліг найбільший тягар Першої світової війни. Якщо вважати, що напередодні війни кількість офіцерів чинної служби сягала приблизно 18 тис., а офіцерів резерву - 14 тис., додати до цього числа всіх офіцерів ландверу, гонведу, звільнених за віком, здоров'ям, і т.п., і знов мобілізованих, то на початок бойових дій чисельність офіцерського складу загалом сягала менше 60 тис. осіб [5, с. 194], при збільшенні армії з 400 тис. до 3 мільйонів. Також важливо врахувати, що втрати офіцерського складу вже на кінець 1914 р. склали лише вбитими 3168 офіцерів, а вибувшими 22310 офіцерів, тобто майже половина довоєнного офіцерського корпусу. Це привело до пришвидшеної підготовки офіцерських кадрів, до складу яких почали потрапляти категорії громадян, які до того не могли бути допущені через стан здоров'я, соціальний статус, неповну середню освіту. Протягом війни офіцерський склад продовжував чисельно зростати передусім за рахунок підготовки офіцерів резерву, на кінець 1915 р. офіцерський склад сягав 130 тис., а на 1 жовтня 1918 р. - 188 тис. офіцерів, 3 яких лише до 35 тис. були чинної служби [5, с. 194].

Висновки. Незважаючи на особливості політичного облаштування «двоєдиної» монархії, тобто фактичне існування двох окремих держав під одною короною, спільне військове міністерство, діючи від особи імператора, приділяло дуже велику увагу створенню системи єдиної підготовки офіцерського складу збройних сил, визначаючи у цьому питанні політику обох 
міністерств крайової оборони (ландверу і гонведу). Тобто, попри «потрійну» структуру збройних сил монархії система підготовки їх командного складу була єдиною.

Ïї метою було підготувати майбутніх офіцерів збройних сил у професійному і ідеологічному плані, що попри певні об'єктивні і суб'єктивні недоліки можна назвати досягнутою. У своїй більшості офіцерський корпус Австро-Угорської армії до кінця залишався вірним присязі і зміг зберегти високий професійний рівень.

Також можна зазначити, що система військової підготовки була позбавлена дискримінації в етнічному чи релігійному сенсі.

1. Вооруженные силы Австро-Венгрии. Главное Управление Генерального Штаба. Изд. отдела Генерал-Квартирмейстера, Часть I: Организация, мобилизация и состав вооруженных сил (по данным 1 января 1912 года), СПб: Военная типография, 1912. - С. 343.

2. Адаменко Д. Императорская и королевская «фасоль». Electronic data. - Mode of access:World Wide Web: http:// warspot.ru/8949-imperatorskaya-i-korolevskaya-fasol (viewed on September 10, 2017). - Title from the screen.

3. Eintheilungsliste des Lehr- und Erziehungspersonales an den k. und k. Militär-Erziehungs- und Bildungsanstalten dem Militärknabenpensionat in Sarajevo und den k. und k. Officierstöchter-Erziehungsinstituten im Schuljahre 1913/1914.Wien, 1913. - S. 101.

4. Janaczek $G$. Tüchtige Officirs und rechtschaffene Männer: Eine historische Bilderreise zu den Militär-Erziehungs und Bildungsanstalten der k.(u.) k. Monarchie. - [Б. м.]: Vitalis, 2007. - S.140.

5. Deák I. Beyond Nationalism. A Social and Political History of the Habsburg Officer Corps 1848-1918. New York. Oxford 1990. - S. 273.

6. THE AUSTRO-HUNGARIAN ARMY 1914-18. For Collectors of its postal items by John Dixon-Nuttall. [Electronic resourse] Chapter 2: Military Service in Austria-Hungary 1914. Appendix $\mathrm{C}$ to chapter 2, Officers, military officials and noncommissioned officers. - Electronic data. - Mode of access: World Wide Web: http://www. austrianphilately.com/dixnut/dn2.htm (viewed on September 08, 2017). - Title from the screen.

7. Schematismus der K. K. Landwehr und der K. K. Gendarmerie der im Reichsrate vertretenen Königreiche und Länder für 1914. - Wien, 1914. - S. 598.

8. Zoltán Miklós. Katonai neveles es kepzes az osztrakmagyar kiegyezestöl az I. vilaghaboru vegeig (1867-1918). Electronic data. - Mode of access: World Wide Web: http://www.zmne.hu/Forum/04otodik/kiegyezes_htm (viewed on September 10, 2017). - Title from the screen. 
9. Wehrgesetz für das Heer in der ö-u. Monarchie. Electronic data. - Mode of access: World Wide Web: http://www.weltkriege.at/Justiz/wehrgesetz.htm (viewed on September 10, 2017). - Title from the screen.

10. Безугольный А.Ю., Ковалевский Н.Ф., Ковалев В.Е. История военно-окружной системы в России 1862-1918. Москва: Центрполиграф, 2012. - С. 463.

Надійшла до редколегії 27.12.2017 р.

Рецензент: М. Р. Надрага, кандидат історичних наук, науковий співробітник Наукового центру Національної академії сухопутних військ імені гетьмана Петра Сагайдачного, м. Львів.

\section{Losiev Oleksandr \\ THE SYSTEM OF TRAINING OFFICERS IN AUSTRO-HUNGARIAN ARMY BEFORE WORLD WAR I}

The article deals with the peculiarities of training officers in Austro-Hungarian army since 70's of the XIX century till the beginning of World War I. The information has been presented in chronological order. The author considers the peculiarities of the structure of Austrian army, the history of the establishment of a system of educational institutions for the professional training of officers in the army, in particular, academies, schools of cadets, and officer specialized courses.

Key words: Austro-Hungarian Armed Forces, the professional training of officers, military academies (Militärakademien), cadet schools (Kadettenschulen), one-year volunteers (Einjährig Freiwillige). 